\title{
Attempts to constrain the fluid flow associated with Uranium Mineralization in the Athabasca Basin using detrital zircons
}

\author{
MORGANN GWENVA PERROT ${ }^{1}$, JOSHUA H.F.L. \\ DAVIES $^{2}$, JESSE R REIMINK ${ }^{3}$, PATRICK LEDRU ${ }^{4}$ AND \\ REMY CHEMILLAC ${ }^{5}$ \\ ${ }^{1}$ McGill \\ ${ }^{2}$ Université du Québec à Montréal \\ ${ }^{3}$ Pennsylvania State University \\ ${ }^{4}$ Université de Lorraine \\ ${ }^{5}$ Orano \\ Presenting Author: perrot.morgann@gmail.com
}

Clastic sedimentary basins consist of abundant detrital (inherited, old) as well as diagenetic (syn-sedimentary) minerals. They also contain fluids that catalyze the formation of diagenetic minerals, as well as interact physically and chemically with the detrital grains. These fluids may be trapped in the basin from ancient seawater during basin formation, and/or migrate through the basin during magmatic or tectonic events. Importantly, this migration process can be associated with mineral deposit formation and/or the concentration of hydrocarbons. Here, we present the initial results of a study intended to understand the timing and genetic relationship between fluid migration events and mineralization, a critical issue for determining the origin of many metal and hydrocarbon deposits. Our study focuses on the chemical composition and $\mathrm{U}-\mathrm{Pb}$ ages of hydrothermally altered zircon and their link with fluid flow events. Three sandstones have been sampled in the heart of the alteration halo of the Cigar lake Uranium (U) deposit in the Athabasca basin, and these samples have been strongly affected by hydrothermal and/or mineralizing fluids associated with uranium mineralization. We analyzed the detrital zircons for their trace element concentrations and $\mathrm{U}-\mathrm{Pb}$ isotopic compositions. The first results suggest that two distinctly different fluids affected the Cigar lake area. One, enriched with $\mathrm{Zn}-\mathrm{Ni}-\mathrm{K}-\mathrm{Al}$ is associated with less hydrothermally altered zircon grains (Lower $\mathrm{Ca}$ and $\mathrm{U}$ concentrations). A second fluid with high Mn-Fe-V-Ti-P-REE is correlated with the more altered grains (higher $\mathrm{Ca}$ and $\mathrm{U}$ ). The ${ }^{207} \mathrm{~Pb} /{ }^{206} \mathrm{~Pb}$ ages of the grains define a representing their crystallization but most individual grains have subsequently undergone intense $\mathrm{Pb}$ loss due to . Though the $\mathrm{Pb}$ loss hinders our ability to precisely date the recrystallization during fluid alteration, our $\mathrm{U}-\mathrm{Pb}$ data and cathodoluminescence (CL) images suggest that recrystallisation and/or metamictisation occurred only locally within each zircon grain. CL imaging of the zircons indicate that the fluids infiltrated cracks in the grains and led to dissolution re-precipitation processes 